\title{
Recurrent Childhood Soft Tissue Sarcoma
}

National Cancer Institute

\section{Source}

National Cancer Institute. Recurrent Childhood Soft Tissue Sarcoma. NCI Thesaurus.

Code C8067.

The reemergence of soft tissue sarcoma in childhood after a period of remission. 